\title{
Root Restriction and Potassium and Calcium Solution Concentrations Affect Dry-matter Production, Cation Uptake, and Blossom-end Rot in Greenhouse Tomato
}

\author{
A. Bar-Tal ${ }^{1}$ and E. Pressman ${ }^{2}$ \\ Agricultural Research Organization, The Volcani Center, Bet Dagan 50250, Israel
}

\begin{abstract}
Additional index words. calcium uptake, potassium uptake, Lycopersicon esculentum
Abstract. Root restriction has been reported to reduce fruit yield, the incidence of blossom end rot (BER) and $K$ concentration in tomato (Lycopersicon esculentum $\mathrm{L}$. ' $\mathrm{F121}$ ') plant organs. The objectives of the present work were to study the effect of root restriction, and combination of $K$ and Ca solution concentrations, on greenhouse tomato fruit yield, quality and cation uptake. Root restriction reduced total yield but improved fruit quality by increasing the dry matter concentration and reducing the incidence of BER. Increasing the $K$ concentration from 5.0 to $10 \mathrm{mmol} \cdot \mathrm{L}^{-1}$ reduced the marketable yield, due to increased incidence of BER. Root restriction decreased $\mathrm{K}$ concentration and $\mathrm{K} / \mathrm{Ca}$ ratio in tomato plant organs, but had no effect on $K$ uptake rate per unit root fresh weight. Increasing $K$ concentration from 2.5 to 10 $\mathbf{m m o l} \cdot \mathrm{L}^{-1}$ increased the $\mathrm{K}$ concentration in plant organs and $\mathrm{K}$ uptake rate, but reduced that of $\mathrm{Ca}$. In contrast, increasing Ca concentration in the solution had no effect on $K$ concentration in plant organs and $K$ uptake rate. The incidence of $B E R$ correlated well with $\mathrm{K} / \mathrm{Ca}$ concentration ratio in the leaves, whereas a poor correlation was obtained with $\mathrm{K} / \mathrm{Ca}$ concentration ratio in ripe fruit.
\end{abstract}

Fruit quality is a crucial factor in the production of greenhouse tomatoes. In a previous experiment we showed that root restriction decreased tomato (Lycopersicon esculentum, 'F121') fruit yield, but reduced the incidence of blossom end rot (BER) in fruit (BarTal et al., 1995). The effect on BER coincided with a reduction in $\mathrm{K}$ concentration in leaves and fruit. Using a high $\mathrm{K} / \mathrm{Ca}$ ratio for the fertilization of tomato plants has been reported to increase the proportion of fruit showing BER (van der Boon, 1973), a physiological disorder whose dependence on $\mathrm{Ca}$ concentration in the fruit is well known (Ho, 1989; Ho et al., 1993; Wiersum, 1966).

Potassium is taken up along the root (Clarkson et al., 1968) and can move via the phloem from leaves to fruit and back to roots. In contrast to $\mathrm{K}, \mathrm{Ca}$ uptake is limited to the very young section of the roots and is transported toward the xylem mainly by apoplastic flux, with little translocation in the phloem (Hanson, 1982). The major pathway for Ca supply to the fruit is a direct transport from the roots via the xylem (Chiu and Bould, 1976; Ho et al., 1993; Wiersum, 1966). Consequently, root restriction may have a differential effect on $\mathrm{K}$ and Ca uptake by plants and on their transport to the developing fruit. Thus, root restriction may affect the incidence of BER via its effect on the balance between $\mathrm{K}$ and $\mathrm{Ca}$ uptake and transport to fruit. There is no information on the combined effects of root restriction and different $\mathrm{K}$ and $\mathrm{Ca}$ concentrations in the solution on fruit yield and BER.

The specific objectives of the present research were to study the combined effect of root restriction and the concentrations of $\mathrm{K}$ and $\mathrm{Ca}$ in nutrient solution on a) fruit yield and the incidence of BER; b) tomato plant dry-matter production; and c) $\mathrm{K}$ and $\mathrm{Ca}$ uptake by tomato plants.

\footnotetext{
Received for publication 21 July 1995. Accepted for publication 14 Feb. 1996 Contribution no. 1680-E, 1995 series, from the Agricultural Research Organization, The Volcani Center, Bet Dagan, Israel. The present study was supported by the CALAR Program, US/AID, contract no. GNE-0158-G00017-00. The skilful assistance of the late S. Sheinfeld, R. Rosenberg, B. Sternbaum, K. Rosenfeld, and R. Shaked is appreciated. The cost of publishing this paper was defrayed in part by the payment of page charges. Under postal regulations, this paper therefore must be hereby marked advertisement solely to indicate this fact.

${ }^{1}$ Institute of Soils and Water; to whom reprint requests should be addressed.

${ }^{2}$ Institute of Field and Garden Crops.
}

\section{Materials and Methods}

Tomato plants were grown in an aerohydroponic system in a greenhouse, as described by Bar-Tal et al. (1994). Seven treatments were applied: two root treatments (restricted in $1.0-\mathrm{L}$ bag and intact); three $\mathrm{K}$ concentrations $\left(\mathrm{C}_{\mathrm{K}}\right)(2.5,5.0$ and 10.0 $\left.\mathrm{mmol} \cdot \mathrm{L}^{-1}\right)$; and two $\mathrm{Ca}$ concentrations $\left(\mathrm{C}_{\mathrm{Ca}}\right)(1.5$ and 3.5 $\mathrm{mmol} \cdot \mathrm{L}^{-1}=3$ and $7 \mathrm{mmol}(+) \mathrm{L}^{-1}$ ) (Table 1 ). The restriction was achieved by confining the roots in bags made of synthetic cloth, which allowed solution changes but not root penetration through the bag (Bar-Tal et al., 1995). Composition of the basic nutrient solution (the lowest $\mathrm{K}$ and Ca concentrations) was $\left(\mathrm{mmol} \cdot \mathrm{L}^{-1}\right): 2.5$ $\mathrm{KNO}_{3}, 1.5 \mathrm{NH}_{4} \mathrm{NO}_{3}, 0.7 \mathrm{H}_{3} \mathrm{PO}_{4}, 0.5 \mathrm{MgSO}_{4}$; to the higher $\mathrm{K}$ treatments 2.5 or $7.5 \mathrm{mmol} \cdot \mathrm{L}^{-1} \mathrm{KCl}$ was added; the high-Ca treatment was obtained by adding $2 \mathrm{mmol} \cdot \mathrm{L}^{-1} \mathrm{CaCl}_{\text {. }}$. Micronutrients were applied with synthetic chelate $\left(\mu \mathrm{mol} \cdot \mathrm{L}^{-1}\right): \mathrm{Fe}, 27.9$ as FeEDDHA; and $\mathrm{Mn}, 10.5$; $\mathrm{Zn}, 4.4$; $\mathrm{Mo}, 0.3$; and $\mathrm{Cu}, 0.7$ as EDTA. The solution also contained $40 \mu \mathrm{mol} \cdot \mathrm{L}^{-1} \mathrm{H}_{3} \mathrm{BO}_{4}$. The solutions were made up using tap water containing $\left(\mathrm{mmol} \cdot \mathrm{L}^{-1}\right)$ : Na, $3-4 ; \mathrm{Ca}$, $1.5 ; \mathrm{Mg}, 0.5 ; \mathrm{Cl}, 4-5 ; \mathrm{NO}_{3}, 0.1-0.2 ; \mathrm{SO}_{4}, 0.5-1.0$. The initial $\mathrm{pH}$ of the solution was about 6.5 . The $\mathrm{pH}$ was monitored daily and when it increased above 7.0 sulfuric acid was added to reduce it to 6.5. The electrical conductivity (EC) was in the range of 1.7-2.3 $\mathrm{mS} \cdot \mathrm{cm}^{-1}$ (the addition of sulfuric acid for $\mathrm{pH}$ adjustment did not change EC significantly). The solution was renewed every 2 weeks and the concentrations of $\mathrm{K}$ and $\mathrm{Ca}$ in the solution were determined before and after replacement. In that period of time $\mathrm{C}_{\mathrm{Ca}}$ decreased to minimum values of 1 and $2.5 \mathrm{mmol} \cdot \mathrm{L}^{-1}$, in the low- and high-Ca treatments, respectively, while $\mathrm{C}_{\mathrm{K}}$ decreased to minimum values of $1.0,3.0$, and $7.5 \mathrm{mmol} \cdot \mathrm{L}^{-1}$, for the $2.5,5.0$, and $10.0 \mathrm{mmol} \cdot \mathrm{L}^{-1}$ treatments, respectively. Nutrient uptake was determined from the change in the solution volume and concentration.

The experiment was arranged in five randomized blocks, each replicate contained twelve plants per plot which were transplanted on 2 Dec. 1992; 15 d after transplanting (DAT) six plants were sampled and after 54 and $92 \mathrm{~d}$ two more plants were sampled, leaving two plants in each plot until the end of the experiment on 25 May 1993, 175 DAT (1 plant $\left./ \mathrm{m}^{2}\right)$. Because of low day and night temperatures $\left(15\right.$ and $10^{\circ} \mathrm{C}$, respectively) and high humidity ( $80 \%$ 
Table 1. A list of treatments applied in this work.

\begin{tabular}{|c|c|c|}
\hline Root treatment & $\mathrm{C}_{\mathrm{K}}$ & $\mathrm{C}_{\mathrm{Ca}}$ \\
\hline Restricted & 2.5 & 3 \\
\hline Restricted & 5.0 & 3 \\
\hline Restricted & 5.0 & 7 \\
\hline Intact & 2.5 & 3 \\
\hline Intact & 5.0 & 3 \\
\hline Intact & 10.0 & 3 \\
\hline Intact & 5.0 & 7 \\
\hline
\end{tabular}

to $100 \%$ ) throughout January, the flowers of the fourth cluster were sprayed with commercial auxins on 26 Jan. 1993 (55 DAT). Onceweekly selective picking of ripe fruit was carried out from 102 DAT to the end of the experiment. The fruit of each truss were weighed separately. Subsamples of tomato fruit from the first, fourth and eighth trusses were taken for determination of dry matter percentage and chemical composition of the fruit. The quality parameters determined were: BER, dry-matter (DM) concentration and total soluble sugar (TSS) concentration. Root volume was determined frequently by water displacement using a calibrated cylinder.

At the end of the experiment, the plants were separated into roots, stems, leaves and fruit. Fresh and dry weights and their K and Ca concentrations were determined. Old leaves of trusses $1+2$ and 3+4+5 were detached on 30 Mar. 1993 and 10 May 1993 (119 and 160 DAT, respectively), and their fresh and dry weights were also determined. For dry weight, organ subsamples were dried in a ventilated $60^{\circ} \mathrm{C}$ oven for 4 to $7 \mathrm{~d}$. Chemical analysis of plant organs was carried out after digestion with nitric acid and perchlorate. Potassium concentration was determined by flame photometer and Ca by atomic absorption spectrophotometry.

Data handling. Potassium and calcium uptake rates, $\mathrm{Q}_{\mathrm{i}}(\mathrm{mmol}(+)$ per plant per day), were calculated by means of the following equations:
$\mathrm{Q}_{\mathrm{i}}=\left(\mathrm{W}_{\mathrm{in}} \times \mathrm{C}_{\mathrm{iin}}+\mathrm{W}_{\mathrm{m}} \times \mathrm{C}_{\mathrm{iW}}-\mathrm{W}_{\mathrm{f}} \times \mathrm{C}_{\mathrm{if}}\right) /(\mathrm{t} \times \mathrm{NP})$

where $\mathrm{i}=\mathrm{K}$ or $\mathrm{Ca}, \mathrm{C}_{\mathrm{iin}}=$ the initial ion solution concentration $\left(\mathrm{mmol}(+) \cdot \mathrm{L}^{-1}\right) ; \mathrm{C}_{\mathrm{iW}}=$ the tap water ion concentration $\left(\mathrm{mmol}(+) \cdot \mathrm{L}^{-1}\right)$; $\mathrm{C}_{\text {if }}=$ the final ion solution concentration after a time interval, $\mathrm{t}$ $\left(\mathrm{mmol}(+) \cdot \mathrm{L}^{-1}\right) ; \mathrm{W}_{\text {in }}=$ the initial water volume in the container (1); $\mathrm{W}_{\mathrm{m}}=$ the water volume added between successive replacements (1); $\mathrm{W}_{\mathrm{f}}=$ the final water volume in the container at the end of the specified time interval (l); $\mathrm{t}=$ the time interval (days) and NP is the number of plants per container.

Nutrient uptake rate per root unit weight, $I_{i}\left(\mathrm{mmol}(+) \cdot \mathrm{g}^{-1} \cdot \mathrm{d}^{-1}\right)$ was calculated as

$\mathrm{I}_{\mathrm{i}}=\mathrm{Q}_{\mathrm{i}} /\left[\left(\mathrm{Rt}_{\mathrm{in}}+\mathrm{Rt}_{\mathrm{f}}\right) / 2\right]$

where $\mathrm{Rt}_{\text {in }}$ and $\mathrm{Rt}_{\mathrm{f}}=$ initial and final root fresh weights $(\mathrm{g})$ at the beginning and the end of the specified time interval, respectively. Root fresh weight was estimated from the measurements of root volume, assuming that root density is $1 \mathrm{~g} \cdot \mathrm{cm}^{-3}$.

The statistical analysis of the experimental data was carried out by the SAS software package (SAS, Cary, N.C.) using the GLM procedure for the analysis of variance, CORR procedure for the correlation analysis and NLIN procedure for determination of coefficients for the nutrient uptake rate equation.

\section{Results and Discussion}

Dry matter production and fruit yield. Root restriction significantly decreased the dry weights of root, stem and leaves (about $30 \%$ ) and fruit (about 20\%) (Table 2). Although root restriction has been reported to reduce DM production, it has been shown that this reduction was not a result of nutrient deficiency (Carmi and Heuer, 1981; Peterson et al., 1991a; Peterson and Krizek, 1992; Ruff et al., 1987). However, Bar-Tal et al. (1995) reported that root restriction reduced both DM production and $\mathrm{K}$ concentration in plant organs,

Table 2. The effect of root restriction and potassium and calcium concentrations in the solution on dry matter production by tomato plant organs (171 days after transplanting).

\begin{tabular}{|c|c|c|c|c|c|c|c|c|}
\hline \multicolumn{3}{|c|}{ Treatment } & & \multicolumn{4}{|c|}{ DM production (g/plant) } & \multirow[b]{3}{*}{ Fruit no. ${ }^{\mathrm{z}} / \mathrm{leaf}(\mathrm{g})$} \\
\hline \multirow[b]{2}{*}{ Root } & \multirow{2}{*}{\multicolumn{2}{|c|}{$\begin{array}{l}\mathrm{C}_{\mathrm{K}} \\
\left(\mathrm{mmol}(+) \mathrm{L}^{-1}\right)\end{array}$}} & \multicolumn{5}{|c|}{ DM production (g/plant) } & \\
\hline & & & Stem & Root & Leaves & Total & Fruit & \\
\hline Restricted & 2.5 & 3 & 143 & 96 & 206 & 445 & 423 & 0.36 \\
\hline Restricted & 5.0 & 3 & 142 & 82 & 210 & 434 & 408 & 0.35 \\
\hline Restricted & 5.0 & 7 & 145 & 93 & 228 & 466 & 347 & 0.33 \\
\hline Mean restricted & 143 & 90 & 215 & 448 & 393 & 0.35 & & \\
\hline Intact 2.5 & 3 & 197 & 135 & 301 & 633 & 521 & 0.28 & \\
\hline Intact 5.0 & 3 & 204 & 132 & 293 & 629 & 450 & 0.28 & \\
\hline Intact 5.0 & 7 & 187 & 129 & 292 & 608 & 522 & 0.28 & \\
\hline Mean intact ${ }^{\mathrm{y}}$ & 196 & 132 & 295 & 623 & 498 & 0.28 & & \\
\hline Intact 10.0 & 3 & 200 & 123 & 292 & 615 & 456 & 0.31 & \\
\hline $\mathrm{LSD}_{0.05}$ & & 40.7 & 25 & 39.1 & 40 & 70 & 0.06 & \\
\hline \multicolumn{9}{|c|}{ Analysis of variance } \\
\hline Variable & & df & \multicolumn{6}{|c|}{ Significance } \\
\hline Root & & 1 & 0.0001 & 0.0001 & 0.0001 & 0.0001 & 0.05 & 0.0001 \\
\hline $\mathrm{C}_{\mathrm{K}}$ & & 2 & NS & NS & NS & NS & NS & NS \\
\hline $\mathrm{C}_{\mathrm{Ca}}^{\mathrm{n}}$ & & 1 & NS & NS & NS & NS & NS & NS \\
\hline Root $\times C_{K}$ & & 1 & NS & NS & NS & NS & NS & NS \\
\hline Root $\times \mathrm{C}_{\mathrm{Ca}}$ & & 1 & NS & NS & NS & NS & NS & NS \\
\hline
\end{tabular}

${ }^{\mathrm{z}}$ Number of fruit per leaf unit weight.

${ }^{\mathrm{y}}$ Mean intact based on the first three treatments of intact-root plants.

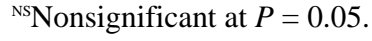


Table 3. Tomato fresh fruit yield, incidence of blossom end rot (BER), and dry matter content in tomatoes of trusses 1 to 8 , as affected by root restriction and $\mathrm{K}$ and $\mathrm{Ca}$ concentrations in the solution.

\begin{tabular}{|c|c|c|c|c|c|c|c|c|c|}
\hline \multicolumn{3}{|c|}{ Treatment } & \multirow[b]{2}{*}{ BER } & \multirow[b]{2}{*}{ Normal } & \multirow[b]{2}{*}{ Total } & & & & \multirow{3}{*}{$\begin{array}{l}\mathrm{DM} \\
(\%)\end{array}$} \\
\hline & $\mathrm{C}_{\mathrm{K}}$ & $\mathrm{C}_{\mathrm{Ca}}$ & & & & BER & Normal & Total & \\
\hline Root & \multicolumn{2}{|c|}{$\left(\operatorname{mmol}(+) \cdot \mathrm{L}^{-1}\right)$} & \multicolumn{3}{|c|}{ Fruit no. } & \multicolumn{3}{|c|}{ Fruit fresh wt (kg/plant) } & \\
\hline Restricted & 2.5 & 3 & 8.8 & 74.0 & 82.8 & 0.51 & 6.5 & 7.0 & 6.7 \\
\hline Restricted & 5.0 & 3 & 4.7 & 70.1 & 74.8 & 0.24 & 6.2 & 6.5 & 7.0 \\
\hline Restricted & 5.0 & 7 & 3.0 & 72.6 & 75.6 & 0.17 & 6.2 & 6.3 & 6.2 \\
\hline Mean restricted & & & 5.5 & 72.2 & 77.7 & 0.31 & 6.3 & 6.6 & 6.6 \\
\hline Intact & 2.5 & 3 & 5.7 & 78.2 & 83.9 & 0.38 & 7.9 & 8.2 & 5.1 \\
\hline Intact & 5.0 & 3 & 11.3 & 71.4 & 82.7 & 0.73 & 7.3 & 8.0 & 4.4 \\
\hline Intact & 5.0 & 7 & 2.8 & 81.9 & 84.7 & 0.12 & 7.9 & 8.0 & 5.5 \\
\hline Mean intact ${ }^{\mathrm{z}}$ & & & 6.6 & 77.2 & 83.8 & 0.41 & 7.7 & 8.1 & 5.0 \\
\hline Intact & 10.0 & 3 & 22.9 & 66.9 & 89.8 & 1.37 & 6.6 & 8.0 & 5.7 \\
\hline $\mathrm{LSD}_{0.05}$ & & & 8.0 & 10 & 12 & 0.44 & 1.0 & 1.0 & 0.92 \\
\hline \multicolumn{10}{|c|}{ Analysis of variance } \\
\hline Variable & & df & & & & nnificanc & & & \\
\hline Root & & 1 & 0.015 & NS & 0.01 & 0.004 & 0.0003 & 0.0001 & 0.0011 \\
\hline $\mathrm{C}_{\mathrm{K}}$ & & 2 & 0.0001 & 0.05 & NS & 0.0001 & 0.03 & NS & NS \\
\hline $\mathrm{C}_{\mathrm{Ca}}$ & & 1 & NS & 0.05 & NS & 0.05 & NS & NS & NS \\
\hline Root $\times \mathrm{C}_{\mathrm{K}}$ & & 1 & NS & NS & NS & 0.05 & NS & NS & NS \\
\hline Root $\times \mathrm{C}_{\mathrm{Ca}}$ & & 1 & NS & NS & NS & NS & NS & NS & NS \\
\hline
\end{tabular}

${ }^{\mathrm{z}}$ Mean intact based on the first three treatments of intact-root plants.

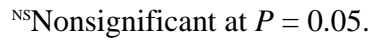

indicating a possible $\mathrm{K}$ deficiency effect of restricting the roots. In the present work the increasing $\mathrm{K}$ and $\mathrm{Ca}$ concentrations in the solution did not significantly affect the dry weight of any plant organ and there was no significant interaction between root restriction and solution composition on any organ dry weight. The reduction in DM production following root restriction could not be compensated by elevating $\mathrm{C}_{\mathrm{Ca}}$ above $3 \mathrm{mmol}(+) \cdot \mathrm{L}^{-1}$ or increasing $\mathrm{C}_{\mathrm{K}}$ above $2.5 \mathrm{mmol} \cdot \mathrm{L}^{-1}$.

These results indicate that the reduction in plant growth under conditions of root restriction was not caused by nutrient deficiency, but it was probably related to hormone synthesis and metabolism in the root system (Carmi and Heuer, 1981; Jackson, 1993; Peterson et al., 1991b; Richards and Rowe, 1977).

Fruit yield and quality. Root restriction reduced the total fruit yield and the number of fruit of the first 8 trusses (Table 3 ). The effect of root restriction on the total yield was greater than its effect on fruit number, because smaller fruit were produced by the rootrestricted plants (data not shown). This is in agreement with previous results (Bar-Tal et al., 1994, 1995).

The major fruit physiological disorder observed in the present study was BER (Table 3), which occurred on trusses 6-8. Root restriction reduced the incidence of BER as found previously (BarTal et al., 1995). This effect was more pronounced in 5.0 $\mathrm{mmol} \cdot \mathrm{L}^{-1} \mathrm{~K}$ and $3 \mathrm{mmol}(+) \cdot \mathrm{L}^{-1} \mathrm{Ca}$ solution, in which the incidence of BER was reduced from 11.3 to 4.7 fruit per plant, and from 0.73 to $0.24 \mathrm{~kg}$ per plant (on a number and weight basis, respectively). Therefore, the negative effect of root restriction on marketable fruit yield was smaller than its effect on the total fruit yield.

We suggest that three factors contributed to the reduction in the incidence of BER by root restriction:

1) Root restriction increased the number of fruit per leaf unit weight (Table 2).

2) Root restriction reduced the growth rate of the fruit.

3) Root restriction reduced the K/Ca concentration ratio in the plants.

The shift in the fruit/leaf ratio probably reduced the transpiration through leaves relative to fruit (a high correlation between leaf weight and leaf area in greenhouse tomato, independent of root restriction, has been reported by Bar-Tal et al., 1995). Since the ratio between the water supply to the fruit from the leaves and that directly from the roots via the xylem is the dominant factor controlling the Ca supply to the fruit (Ehret and Ho, 1986b; Ho et al., 1987; Wiersum, 1966), it can be considered that increased fruit number per leaf area could contribute to an increased Ca supply to the developing fruit and to reduced incidence of BER. The second factor to affect the incidence of BER, fruit growth, was reported by Ho et al. (1993). In the present experiment we found that root restriction had no effect on the timing of anthesis and on ripening, therefore, the growth rate of the fruit of restricted-root plants was reduced by root restriction. The third factor that may affects the incidence of BER, the $\mathrm{K} / \mathrm{Ca}$ ratio in the plant organs, will be discussed.

Solution composition had no significant effect on the number of fruit and their total weight, but it affected the incidence of BER, and through it, the marketable fruit yield (Table 3). Increasing $C_{K}$ from 2.5 to $10.0 \mathrm{mmol} \cdot \mathrm{L}^{-1}$ increased the incidence of BER from 5.7 to 22.9 fruit per plant and reduced the marketable fruit yield from 78.2 to 66.9 fruit per plant. Elevating $\mathrm{C}_{\mathrm{Ca}}$ from 3 to $7 \mathrm{mmol}(+) \cdot \mathrm{L}^{-1}$ of intact root plants significantly increased the number of marketable fruit from 71.4 to 81.9 fruit per plant, because of the reduction in the incidence of BER from 11.3 to 2.8 fruit/plant.

A STEPWISE analysis (SAS, Cary, NC) of the effects of the studied factors on the incidence of BER showed that the incidence of BER-affected fruit (BLWT, weight basis) was a function of the $\mathrm{K} / \mathrm{Ca}$ concentration ratio in the solution

$$
\mathrm{BLWT}=-69.8+543.7 \mathrm{C}_{\mathrm{K}} / \mathrm{C}_{\mathrm{Ca}}, r^{2}=0.50
$$

The effect of $\mathrm{C}_{\mathrm{K}} / \mathrm{C}_{\mathrm{Ca}}$ was significant $(P<0.0001)$ and is the only significant factor that was found to affect the incidence of BER. Such an increase in BER as a result of increased $\mathrm{K}$ fertilization is well documented (van der Boon, 1973; Winsor and Adams, 1987).

A STEPWISE analysis of the total fruit yield (TOTALWT) as a function of root treatment and solution composition yielded the following equation: 
Table 4. The effects of root restriction, $\mathrm{C}_{\mathrm{K}}$, and $\mathrm{C}_{\mathrm{Ca}}$ on $\mathrm{K}$ concentration in tomato plant organs (171 days after transplanting).

\begin{tabular}{|c|c|c|c|c|c|c|c|c|c|c|}
\hline \multicolumn{3}{|c|}{ Treatment } & \multicolumn{8}{|c|}{$\mathrm{K}$ concn $\left(\mathrm{mg} \cdot \mathrm{g}^{-1}\right)$} \\
\hline \multirow[b]{2}{*}{ Root } & \multirow{2}{*}{\multicolumn{2}{|c|}{$\begin{array}{l}\mathrm{C}_{\mathrm{K}} \quad \mathrm{C}_{\mathrm{Ca}} \\
\left(\mathrm{mmol}(+) \cdot \mathrm{L}^{-1}\right)\end{array}$}} & \multirow[b]{2}{*}{ Root } & \multirow[b]{2}{*}{ Stem } & \multicolumn{3}{|c|}{ Leaves of trusses } & \multicolumn{3}{|c|}{ Fruit of trusses } \\
\hline & & & & & $1-2$ & $3-5$ & $6-8$ & 1 & 4 & 8 \\
\hline Restricted & 2.5 & 3 & 24.2 & 28.0 & 55.4 & 39.2 & 31.6 & 48.8 & 38.0 & 30.1 \\
\hline Restricted & 5.0 & 3 & 31.1 & 28.6 & 59.5 & 39.5 & 31.0 & 45.0 & 36.3 & 30.3 \\
\hline Restricted & 5.0 & 7 & 34.5 & 28.4 & 55.0 & 42.0 & 31.3 & 56.8 & 36.7 & 33.5 \\
\hline Mean restricted & & & 29.9 & 28.3 & 56.6 & 40.2 & 31.3 & 50.2 & 37.0 & 31.3 \\
\hline Intact & 2.5 & 3 & 31.8 & 30.2 & 55.8 & 43.8 & 33.4 & 51.4 & 41.0 & 36.3 \\
\hline Intact & 5.0 & 3 & 39.7 & 31.2 & 57.8 & 49.0 & 37.6 & 51.6 & 42.5 & 38.3 \\
\hline Intact & 5.0 & 7 & 40.8 & 33.5 & 57.0 & 46.3 & 34.3 & 58.5 & 41.8 & 36.4 \\
\hline Mean intact ${ }^{\mathrm{Z}}$ & & & 37.4 & 31.6 & 56.9 & 46.4 & 35.1 & 53.8 & 41.8 & 37.0 \\
\hline Intact & 10.0 & 3 & 46.0 & 35.0 & 69.4 & 56.2 & 44.0 & 54.6 & 39.0 & 38.5 \\
\hline $\begin{array}{l}\mathrm{LSD}_{0.05} \\
\text { Analysis of varian }\end{array}$ & & & 5.6 & 2.2 & 4.8 & 4.0 & 2.7 & 10.5 & 7.8 & 7.5 \\
\hline Variable & & $\mathrm{df}$ & & & & Sign & ance & & & \\
\hline Root & & 1 & 0.0001 & 0.009 & 0.044 & 0.0001 & 0.0001 & NS & 0.07 & 0.0003 \\
\hline $\mathrm{C}_{\mathrm{K}}$ & & 2 & 0.009 & 0.06 & 0.002 & 0.0009 & 0.0001 & NS & NS & NS \\
\hline $\mathrm{C}_{\mathrm{Ca}}$ & & 1 & NS & NS & NS & NS & NS & 0.03 & NS & NS \\
\hline Root $\times C_{K}$ & & 1 & NS & NS & NS & NS & NS & NS & NS & NS \\
\hline Root $\times \mathrm{C}_{\mathrm{Ca}}$ & & 1 & NS & NS & NS & NS & NS & NS & NS & 0.013 \\
\hline
\end{tabular}

${ }^{\mathrm{z}}$ Mean intact based on the first three treatments of intact-root plants.

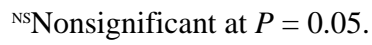

TOTALWT $=5091.9+3061.7$ ROOT, $r^{2}=0.51$

in which ROOT $=1.0$ or 0.5 for intact or restricted roots, respectively. The effect of the root treatment is significant $(P<0.0001)$. Such an effect of root restriction on total yield was also reported by Bar-Tal et al. (1995). Note that no other parameter, including $C_{K}$ and $\mathrm{C}_{\mathrm{Ca}}$ and their ratio, had a significant effect. For the marketable fruit yield, defined as fruit not affected by BER (MARKETWT), the following equation was obtained:

MARKETWT $=6404.3+1944.7$ ROOT $^{2}-685.9 \mathrm{C}_{\mathrm{K}} / \mathrm{C}_{\mathrm{Ca}}, r^{2}=0.49$
Both effects were significant $(P<0.0001)$.

Root restriction increased the dry matter (DM) concentration in the fruit (Table 3). Measurements of the total soluble solids concentration (TSS) in subsample from each treatment indicated that root restriction increased the TSS from $4.6 \%$ to $6.1 \%$ (data not shown because of lack of statistical analysis of this parameter). The effect of root restriction on the DM concentration is probably a result of reduced water uptake by the fruit of restricted-root plants. Bar-Yosef et al. (1980), reported that a smaller root mass, caused by increased irrigation frequency reduced fresh fruit yield but did not affect fruit dry weight, because the fruit of small-root-volume

Table 5. The effects of root restriction, $\mathrm{C}_{\mathrm{K}}$, and $\mathrm{C}_{\mathrm{Ca}}$ on Ca concentration in tomato plant organs (171 days after transplanting).

\begin{tabular}{|c|c|c|c|c|c|c|c|c|c|c|}
\hline \multicolumn{3}{|c|}{ Treatment } & \multicolumn{8}{|c|}{ Ca concn $\left(\mathrm{mg} \cdot \mathrm{g}^{-1}\right)$} \\
\hline \multirow[b]{2}{*}{ Root } & \multirow{2}{*}{\multicolumn{2}{|c|}{$\begin{array}{ll}\mathrm{C}_{\mathrm{K}} & \mathrm{C}_{\mathrm{Ca}} \\
\left(\mathrm{mmol}(+) \cdot \mathrm{L}^{-1}\right)\end{array}$}} & \multirow[b]{2}{*}{ Root } & \multirow[b]{2}{*}{ Stem } & \multicolumn{3}{|c|}{ Leaves of trusses } & \multicolumn{3}{|c|}{ Fruit of trusses } \\
\hline & & & & & $1-2$ & $3-5$ & $6-8$ & 1 & 4 & 8 \\
\hline Restricted & 2.5 & 3 & 6.7 & 8.0 & 45 & 44 & 44 & 1.4 & 1.7 & 1.1 \\
\hline Restricted & 5.0 & 3 & 6.6 & 7.0 & 46 & 48 & 44 & 1.3 & 1.4 & 0.9 \\
\hline Restricted & 5.0 & 7 & 10.6 & 9.5 & 55 & 55 & 52 & 2.1 & 1.5 & 1.2 \\
\hline Mean restricted & & & 8.0 & 8.2 & 48.9 & 49.0 & 46.7 & 1.6 & 1.5 & 1.1 \\
\hline Intact & 2.5 & 3 & 8.9 & 7.9 & 45 & 47 & 46 & 1.7 & 1.7 & 1.3 \\
\hline Intact & 5.0 & 3 & 9.6 & 8.3 & 47 & 49 & 45 & 1.4 & 1.7 & 1.6 \\
\hline Intact & 5.0 & 7 & 19.0 & 10.9 & 55 & 57 & 51 & 1.9 & 2.0 & 1.2 \\
\hline Mean intact ${ }^{\mathrm{y}}$ & & & 12.5 & 9.0 & 49.0 & 51.0 & 47.3 & 1.7 & 1.8 & 1.4 \\
\hline Intact & 10.0 & 3 & 7.5 & 6.6 & 42 & 44 & 41 & 1.4 & 1.4 & 1.0 \\
\hline $\mathrm{LSD}_{0.05}$ & & & 3.3 & 1.0 & 3.4 & 5.5 & 5.5 & 0.35 & 0.4 & 0.3 \\
\hline \multicolumn{11}{|c|}{ Analysis of variance } \\
\hline Variable & & df & \multicolumn{8}{|c|}{ Significance } \\
\hline Root & & 1 & 0.003 & NS & NS & NS & NS & NS & NS & 0.025 \\
\hline $\mathrm{C}_{\mathrm{K}}$ & & 2 & 0.0001 & 0.0001 & 0.0001 & 0.0002 & 0.004 & NS & 0.08 & 0.010 \\
\hline $\mathrm{C}_{\mathrm{Ca}}^{\mathrm{K}}$ & & 1 & 0.0001 & 0.0001 & 0.0001 & 0.0002 & 0.0001 & 0.0001 & NS & NS \\
\hline Root $\times C_{K}$ & & 1 & NS & 0.020 & NS & NS & NS & NS & NS & NS \\
\hline Root $\times \mathrm{C}_{\mathrm{Ca}}$ & & 1 & NS & NS & NS & NS & NS & NS & NS & 0.003 \\
\hline
\end{tabular}

${ }_{\mathrm{z}}$ Mean intact based on the first three treatments of intact-root plants.

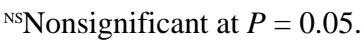


Table 6. The effects of root restriction, $\mathrm{C}_{\mathrm{K}}$, and $\mathrm{C}_{\mathrm{Ca}}$ on $\mathrm{K} / \mathrm{Ca}$ ratio in tomato plant leaves (171 days after transplanting) and fruit.

\begin{tabular}{|c|c|c|c|c|c|c|c|c|}
\hline \multicolumn{3}{|c|}{ Treatment } & \multicolumn{6}{|c|}{$\mathrm{K} / \mathrm{Ca}$ ratio } \\
\hline \multirow[b]{2}{*}{ Root } & $\mathrm{C}_{\mathrm{K}}$ & \multirow{2}{*}{${ }_{1} \mathrm{C}_{\mathrm{Ca}}$} & \multicolumn{3}{|c|}{ Leaves of trusses } & \multicolumn{3}{|c|}{ Fruit of trusses } \\
\hline & $\left(\operatorname{mmol}(+) \cdot \mathrm{L}^{-1}\right)$ & & $1-2$ & $3-5$ & $6-8$ & 1 & 4 & 8 \\
\hline Restricted & 2.5 & 3 & 1.23 & 0.89 & 0.72 & 34.9 & 22.3 & 27.4 \\
\hline Restricted & 5.0 & 3 & 1.29 & 0.82 & 0.70 & 34.6 & 25.9 & 33.7 \\
\hline Restricted & 5.0 & 7 & 1.00 & 0.76 & 0.60 & 27.0 & 24.5 & 27.9 \\
\hline Mean restricted & & & 1.17 & 0.82 & 0.67 & 32.2 & 24.2 & 29.7 \\
\hline Intact & 2.5 & 3 & 1.24 & 0.93 & 0.73 & 30.2 & 24.1 & 27.9 \\
\hline Intact & 5.0 & 3 & 1.23 & 1.00 & 0.84 & 36.9 & 25.0 & 23.9 \\
\hline Intact & 5.0 & 7 & 1.04 & 0.81 & 0.67 & 30.8 & 20.9 & 30.3 \\
\hline Mean intact ${ }^{\mathrm{z}}$ & & & 1.17 & 0.91 & 0.75 & 32.6 & 23.3 & 27.4 \\
\hline Intact & 10.0 & 3 & 1.65 & 1.28 & 1.07 & 39.0 & 27.9 & 38.5 \\
\hline $\mathrm{LSD}_{0.05}$ & & & 0.14 & 0.11 & 0.11 & 5.4 & 3.6 & 4.4 \\
\hline \multicolumn{9}{|c|}{ Analysis of variance } \\
\hline Variable & & $\mathrm{df}$ & \multicolumn{6}{|c|}{ Significance } \\
\hline Root & & 1 & 0.014 & 0.0001 & 0.002 & NS & NS & NS \\
\hline $\mathrm{C}_{\mathrm{K}}$ & & 2 & 0.0001 & 0.0001 & 0.0001 & 0.07 & 0.09 & 0.0007 \\
\hline $\mathrm{C}_{\mathrm{Ca}}$ & & 1 & 0.043 & 0.043 & 0.01 & 0.01 & 0.11 & NS \\
\hline Root $\times C_{K}$ & & 1 & NS & NS & NS & NS & NS & NS \\
\hline Root $\times \mathrm{C}_{\mathrm{Ca}}$ & & 1 & NS & NS & NS & NS & NS & NS \\
\hline
\end{tabular}

${ }^{\mathrm{z}}$ Mean intact based on the first three treatments of intact-root plants.

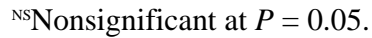

plants had a higher dry matter concentration. Ehret and Ho (1986a) reported that increased salinity of the solution up to $17 \mathrm{mS} \cdot \mathrm{cm}^{-1}$ reduced fruit fresh weight but had no effect on its dry weight. Potassium and calcium concentrations in the solution had no significant effect on the DM concentration in the fruit (Table 3).

Nutrient concentration in plant organs. Potassium concentration in tomato plant organs decreased as a function of plant age (data not shown) and leaf position on the plant (Table 4), in agreement with previous results for the same cultivar (Bar-Yosef, 1990, unpublished data). Raising $C_{K}$ from 2.5 to 5 and to 10 $\mathrm{mmol} \cdot \mathrm{L}^{-1}$ generally increased the $\mathrm{K}$ concentration in root, stem and leaves, but had no significant effect on $\mathrm{K}$ concentration in ripe fruit (Table 4). Ca concentration in the solution had no significant effect on K concentration in these organs, but increased it in the fruit of truss 1. An interactive effect of $\mathrm{C}_{\mathrm{Ca}}$ and root restriction on $\mathrm{K}$ concentration in the fruit of truss 8 was found; increased $\mathrm{C}_{\mathrm{Ca}}$ slightly increased $\mathrm{K}$ concentration in the fruit of root-restricted plants, but had the opposite effect on the fruit of intact-root plants. Root restriction significantly reduced $\mathrm{K}$ concentration in the root, stem, leaves and fruit, in agreement with previous results (Bar-Tal et al., 1995).

Calcium concentration in plant organs increased with plant age (data not shown), but there was no significant effect of leaf position on leaf Ca concentration (Table 5). Calcium concentration in the fruit was much lower than in the leaves. Increasing $\mathrm{C}_{\mathrm{K}}$ above 5 $\mathrm{mmol} \cdot \mathrm{L}^{-1}$ reduced the Ca concentration of root, stem, leaf and fruit of truss 8. Raising $\mathrm{C}_{\mathrm{Ca}}$ significantly increased the $\mathrm{Ca}$ concentration in all plant vegetative organs and the fruit of truss 1 . Root restriction reduced $\mathrm{Ca}$ concentration in the roots but, in contrast to its effect on potassium concentration, it had no significant effect on $\mathrm{Ca}$ concentration in the stem, leaves and fruit, excepting the fruit of truss 8 .

The reduction in $\mathrm{K}$ concentration (Table 4) and the increase in Ca concentration (Table 5) as a function of plant age and leaf position, brought up a decrease in the $\mathrm{K} / \mathrm{Ca}$ ratio in tomato plant organs as a function of plant age (data not shown) and leaf position on the plant (Table 6). Raising $\mathrm{C}_{\mathrm{K}}$ from 2.5 to 5 and to $10 \mathrm{mmol} \cdot \mathrm{L}^{-}$ ${ }^{1}$ significantly increased the $\mathrm{K} / \mathrm{Ca}$ ratio in the leaves and the ripe fruit of truss 8 . Raising $\mathrm{C}_{\mathrm{Ca}}$ from 3.0 to $7.0 \mathrm{mmol} \cdot \mathrm{L}^{-1}$ significantly decreased the $\mathrm{K} / \mathrm{Ca}$ ratio in the leaves and the fruit of truss 1 . Root restriction significantly reduced the $\mathrm{K} / \mathrm{Ca}$ ratio in the leaves but had no significant effect on this ratio in the fruit.

Although the relationship between Ca concentration in tomato fruit and the incidence of BER is well known (van der Boon, 1973; Winsor and Adams, 1987), we found a very poor correlation between the incidence of BER, the concentrations of $\mathrm{Ca}$ and $\mathrm{K}$ and the $\mathrm{K} / \mathrm{Ca}$ ratio, in fruit samples from trusses 1,4 , and 8 . There was a good correlation between the incidence of BER and $\mathrm{K}$ concentration in the leaves adjacent to trusses $3-5$ and 6-8: $r=0.65$ and 0.69 , respectively, with $t=0.0001$. A lower correlation was found between the incidence of BER and $\mathrm{Ca}$ concentration in these leaves: $r=-0.48$ and -0.54 with $t=0.004$ and 0.001 . A higher correlation was found between the incidence of BER and the K/Ca ratio in these leaves: $r=0.82$ and 0.79 with $t=0.0001$.

Although the Ca supply to the fruit is considered to be an important factor in the occurrence of BER, efforts to define critical values or even to correlate BER incidence with $\mathrm{Ca}$ concentration or K/Ca ratio in fruit have not succeeded (Chiu and Bould, 1976). The possible reasons are

1) The tomato fruit is susceptible to the Ca concentration and the $\mathrm{K} / \mathrm{Ca}$ ratio during a very specific short period in its early development (Ehret and Ho, 1986b; Ho, 1989; Ho et al., 1993).

2) The Ca concentration in the fruit is very low and varies with the distance from the distal part to the blossom end (Ehret and Ho, 1986b; Ho et al., 1987).

Calcium concentration and the $\mathrm{K} / \mathrm{Ca}$ ratio in the leaves have been considered poor indicators of $\mathrm{Ca}$ concentration and $\mathrm{K} / \mathrm{Ca}$ ratio in the fruit, because $\mathrm{Ca}$ transport from leaves to fruit is negligible (Ho et al., 1987; Ho et al., 1993). Nevertheless, our data show that $\mathrm{K}$ and $\mathrm{Ca}$ concentrations and their ratio in the leaves adjacent to the studied truss provided an indication of BER incidence.

Rate of potassium and calcium uptake. The relationship between $\mathrm{C}_{\mathrm{K}}$ and $\mathrm{K}$ uptake rate per root fresh weight $\left(\mathrm{I}_{\mathrm{K}}\right), 55$ and 163 $\mathrm{d}$ after transplanting, is presented in Fig. 1. $\mathrm{I}_{\mathrm{K}}$ was higher in the 


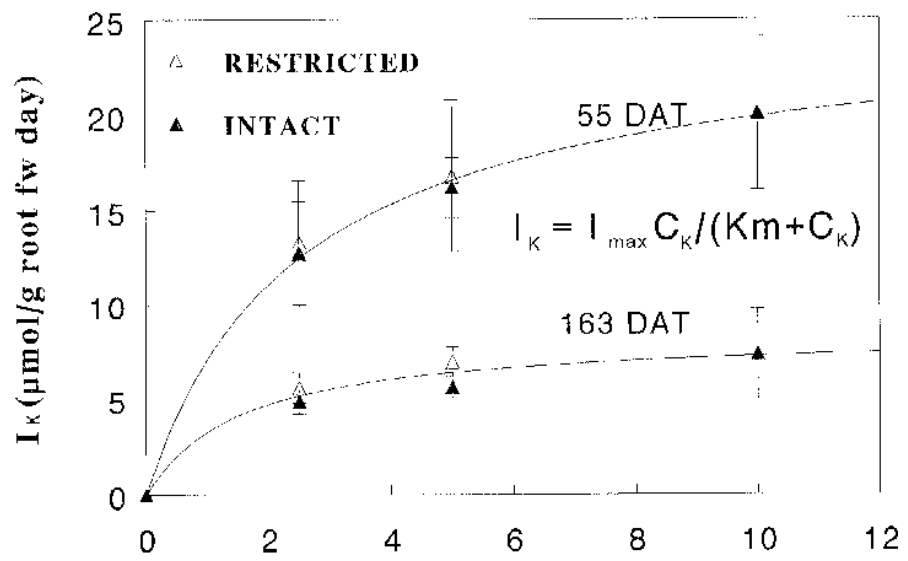

K CONCENTRATION (mmo/l)

Fig. 1. Potassium uptake rate per unit root fresh weight of tomato plant as a function of $\mathrm{K}$ concentration in the solution. The vertical bars are $\mathrm{LSD}_{0.05}$. The lines are calculated by a Michaelis-Menten model with parameters fitted to the observed results by the NLIN procedure (SAS Institute, Cary, N.C.).

\begin{tabular}{|c|c|c|c|c|}
\hline \multirow[b]{2}{*}{ Parameter } & \multicolumn{2}{|c|}{$55 \operatorname{DAT}(26 / 1)$} & \multicolumn{2}{|c|}{163 DAT (13/5) } \\
\hline & $\begin{array}{c}\mathrm{K}_{\mathrm{m}} \\
\mathrm{mmol} \cdot \mathrm{L}^{-1}\end{array}$ & $\begin{array}{c}\mathrm{F}_{\max } \\
\mathrm{mmol} \cdot \mathrm{g}^{-1} \cdot \mathrm{d}^{-1}\end{array}$ & $\begin{array}{c}\mathrm{K}_{\mathrm{m}} \\
\mathrm{mmol} \cdot \mathrm{L}^{-1}\end{array}$ & $\begin{array}{c}\mathrm{F}_{\max } \\
\mathrm{mmol} \cdot \mathrm{g}^{-1} \cdot \mathrm{d}^{-1}\end{array}$ \\
\hline Value & 2.2 & 24.3 & 1.57 & 8.4 \\
\hline SE & 0.21 & 0.74 & 0.60 & 0.86 \\
\hline $\mathrm{T}$ & 10.6 & 32.7 & 2.6 & 18.4 \\
\hline Probability & 0.001 & 0.001 & 0.1 & 0.001 \\
\hline SEE & \multicolumn{2}{|c|}{0.36} & \multicolumn{2}{|c|}{0.49} \\
\hline
\end{tabular}

younger than in the older plants, in agreement with published results (Clarkson et al., 1968; Warncke and Barber, 1974). In young plants, increasing $\mathrm{C}_{\mathrm{K}}$ from 2.5 to $5.0 \mathrm{mmol} \cdot \mathrm{L}^{-1}$, increased $\mathrm{I}_{\mathrm{K}}$, but a further increase in $\mathrm{C}_{\mathrm{K}}$ to $10 \mathrm{mmol} \cdot \mathrm{L}^{-1}$ affected $\mathrm{I}_{\mathrm{K}}$ only slightly. In older plants, the effect of increasing $\mathrm{C}_{\mathrm{K}}$ from 2.5 to 10.0 $\mathrm{mmol} \cdot \mathrm{L}^{-1}$ was very small, therefore it could not ameliorate the adverse effects of the restricted root system on the rate of $\mathrm{K}$ uptake per plant. Calcium concentration had no significant effect on $I_{K}$ (data not shown), as it did not affect either K uptake per plant or K concentration in tomato organs. Root restriction significantly reduced the $\mathrm{K}$ uptake rate per plant (data not shown) but it had no effect on $\mathrm{I}_{\mathrm{K}}$.

A Michaelis-Menten type equation (Fig. 1) described $(P<$ $0.005)$ the relationship between $I_{K}$ and $C_{K}$ well for intact- and restricted-root plants together, at the two dates considered. The values of the parameter $\mathrm{I}_{\max }\left(24.9\right.$ and $8.8 \mu \mathrm{mol} \cdot \mathrm{g}^{-1} \cdot \mathrm{d}^{-1}$, for the young and old plants, respectively) fell in the range of published data for four different species (Wild et al., 1974). Bar-Yosef and Sagiv (1985) estimated a higher maximal $I_{K}$ value, of 110 $\mu \mathrm{mol} \cdot \mathrm{g}^{-1} \cdot \mathrm{d}^{-1}$, for greenhouse tomato (Lycopersicon esculentum, 'Grandier') grown in soil, but a lower value, of $8.6 \mu \mathrm{mol} \cdot \mathrm{g}^{-1} \cdot \mathrm{d}^{-1}$, was found by Bar-Yosef et al. (1992, unpublished data) for another cultivar of tomato ('F144'). The values found for the parameter $\mathrm{K}_{\mathrm{m}}$ ( 2.22 to $1.57 \mathrm{mmol} \cdot \mathrm{L}^{-1}$ ) were appreciably higher than those reported for other plant species growing in flowing or well-stirred solution (Barber, 1984). One reason for the greater $\mathrm{K}_{\mathrm{m}}$ is probably that the mechanism for $\mathrm{K}$ uptake differs between the low and high ranges of solution concentration (up to 0.5 and $50 \mathrm{mmol} \cdot \mathrm{L}^{-1}$, respectively). Epstein et al. (1963) obtained $\mathrm{K}_{\mathrm{m}}$ values of 18 $\mu \mathrm{mol} \cdot \mathrm{L}^{-1}$ for mechanism I and $16 \mathrm{mmol} \cdot \mathrm{L}^{-1}$ for mechanism II. The $\mathrm{K}_{\mathrm{m}}$ obtained for the older plants, 163 DAT, was not significant, indicating that lower values of $\mathrm{C}_{\mathrm{K}}$ were required for estimation of this parameter. According to Bar-Yosef et al. (1993, unpublished data) an increase in K concentration in the irrigation water from 3.2 to $10.7 \mathrm{mmol} \cdot \mathrm{L}^{-1}$ did not result in an increased $\mathrm{K}$ uptake rate, in agreement with the curve in Fig. 1. Root restriction did not affect $\mathrm{I}_{\mathrm{K}}$ (Fig. 1), although it enhanced $\mathrm{N}$ uptake rate per unit root fresh weight (Bar-Tal et al., 1995).

The relationship between $\mathrm{C}_{\mathrm{K}}$ and $\mathrm{Ca}$ uptake rate per unit root fresh weight $\left(\mathrm{I}_{\mathrm{Ca}}\right), 55$ and $163 \mathrm{~d}$ after transplanting, is presented in Fig. 2. Like $\mathrm{I}_{\mathrm{K}}, \mathrm{I}_{\mathrm{Ca}}$ was usually greater in the younger than in older plants. In young plants $\mathrm{I}_{\mathrm{Ca}}$ decreased linearly as $\mathrm{C}_{\mathrm{K}}$ increased from 2.5 to $10.0 \mathrm{mmol} \cdot \mathrm{L}^{-1}$ whereas, in the older plants $\mathrm{I}_{\mathrm{Ca}}$ was unaffected by $\mathrm{C}_{\mathrm{K}}$. Raising $\mathrm{C}_{\mathrm{ca}}$ from 3 to $7 \mathrm{mmol} \cdot \mathrm{L}^{-1}$ enhanced $\mathrm{I}_{\mathrm{Ca}}$, in agreement with the higher $\mathrm{Ca}$ concentration in plant organs obtained in this treatment. Root restriction decreased Ca uptake rate per plant (data not shown), but there was a trend of an increased $\mathrm{I}_{\mathrm{Ca}}$ by root restriction combined with low $\mathrm{C}_{\mathrm{K}}$. This phenomenon is consistent with the ability of the restricted-root plants to maintain Ca concentrations in plant organs similar to those in intact-root plants. However, the effect of root restriction on $\mathrm{I}_{\mathrm{Ca}}$ was not significant.

\section{Conclusions}

Although root restriction reduced both DM production and $\mathrm{K}$ concentration in plant organs, even the lowest values of K concentration found in the leaves of the upper trusses of root-restricted plants were above the deficiency range. The reduction in DM production following root restriction could not be compensated by elevating $\mathrm{C}_{\mathrm{Ca}}$ above $3 \mathrm{mmol}(+) \mathrm{L}^{-1}$ or increasing $\mathrm{C}_{\mathrm{K}}$ above 2.5 $\mathrm{mmol} \cdot \mathrm{L}^{-1}$.

The results of the present study indicate that root restriction improved two fruit-quality parameters: it raised the DM concentration in the fruit and it reduced BER incidence. The effect of root restriction on the DM concentration is probably a result of reduced water uptake by the fruit of root-restricted plants.

The reduction of BER incidence by root restriction was probably a result of

1) Increased number of fruit per leaf area relative to that of the plants with intact roots. Therefore, root restriction probably reduced the $\mathrm{Ca}$ transport by transpiration through leaves relative to fruit.

2) Reduced growth rate of the fruit of root-restricted plants relative to that of the plants with intact roots.

3) Reduced K/Ca concentration ratio in the root-restricted plants

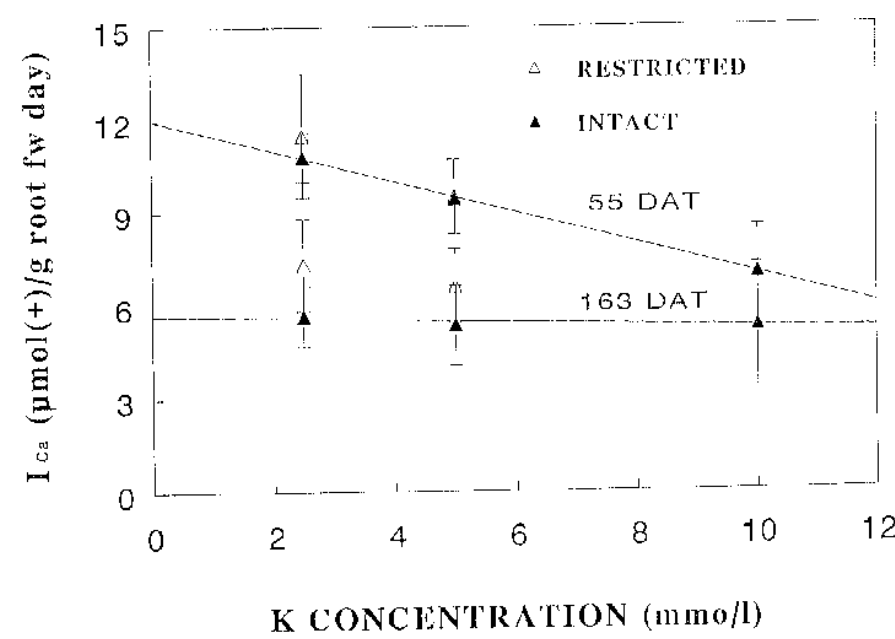

Fig. 2. Calcium uptake rate per unit root fresh weight of tomato plant as a function of $\mathrm{K}$ concentration in the solution. The vertical bars are $\mathrm{LSD}_{0.05}$. 
relative to that of the plants with intact roots. The effect of root restriction on the K/Ca ratio was clearly expressed in the leaves. There was good correlation of the incidence of BER with the K/ $\mathrm{Ca}$ ratio in the leaves. Our data show that $\mathrm{K}$ and $\mathrm{Ca}$ concentrations and their ratio in the leaves adjacent to the studied truss provided an indication of BER incidence.

\section{Literature Cited}

Barber, S.A. 1984. Potassium, p. 229-258. In S.A. Barber (ed.). Soil nutrient bioavailability. Wiley, New York.

Bar-Tal, A., A. Feigin, I. Rylski, and E. Pressman. 1994. Root pruning and $\mathrm{N}-\mathrm{NO}_{3}$ solution concentration effects on tomato plant growth and fruit yield. Sci. Hort. 58:91-103.

Bar-Tal, A., A. Feigin, S. Sheinfeld, R. Rosenberg, B. Sternbaum, I. Rylski, and E. Pressman. 1995. Root restriction and $\mathrm{N}-\mathrm{NO}_{3}$ solution concentration effects on nutrient uptake, transpiration and dry matter production of tomato. Sci. Hort. 63:195-208.

Bar-Yosef, B., C. Stammers, and B. Sagiv. 1980. Growth of trickleirrigated tomato as related to rooting volume and uptake of $\mathrm{N}$ and water. Agron. J. 72:815-822.

Bar-Yosef, B. and B. Sagiv. 1985. Potassium supply to field crops grown under drip irrigation and fertilization. In: Proc. Potassium Symposium, Pretoria, Intl. Potash Institute, Bern.

Boon, van der, J. 1973. Influence of K/Ca ratio and drought on physiological disorders in tomato. Netherlands J. Agr. Sci. 21:56-67.

Carmi, A. and B. Heuer. 1981. The role of roots in control of bean shoot growth. Ann. Bot. 48:519-527.

Chiu, T.F. and C. Bould. 1976. Effects of shortage of calcium and other cations on ${ }^{45} \mathrm{Ca}$ mobility, growth and nutritional disorders of tomato plants (Lycopersicon esculentum). J. Sci. Food Agr. 27:969-977.

Clarkson, D.T., J. Sanderson, and R.S. Russel. 1968. Ion uptake and root age. Nature (London) 220:805-806.

Ehret, D.L. and L.C. Ho. 1986a. The effect of salinity on dry matter partitioning and fruit growth in tomatoes grown in nutrient film culture. J. Hort. Sci. 61:361-367.

Ehret, D.L. and L.C. Ho. 1986b. Translocation of calcium in relation to tomato fruit growth. Ann. Bot. 58:679-688.

Epstein, E., D.W. Rains, and E.O. Elzam. 1963. Resolution of dual mechanisms of potassium absorption by barley roots. Proc. Natl. Acad. Sci. 49:684-692.

Hanson, J.B. 1982. The function of calcium in plant nutrition. Adv. Plant Nutr. 1:149-159.

Ho, L.C., R.I. Grange, and A.J. Picken. 1987. An analysis of the accumulation of water and dry matter in tomato fruit. Plant Cell Environ. 10:157-162.

Ho, L.C. 1989. Environmental effects on the diurnal accumulation of ${ }^{45} \mathrm{Ca}$ by young fruits and leaves of tomato plants. Ann. Bot. 63:281-288.

Ho, L.C., R. Belda, M. Brown, J. Andrews, and P. Adams. 1993. Uptake and transport of calcium and the possible causes of blossom-end rot in tomato. J. Expt. Bot. 44:509-518.

Jackson, M.B. 1993. Are plant hormones involved in root to shoot communication? Adv. Bot. Res. 19:104-187.

Peterson, T.A., M.D. Reinsel, and D.T. Krizek. 1991a. Tomato (Lycopersicon esculentum Mill., cv. 'Better Bush') plant response to root restriction. 1. Alteration of plant morphology. J. Expt. Bot. 42:1233-1240.

Peterson, T.A., M.D. Reinsel, and D.T. Krizek. 1991b. Tomato (Lycopersicon esculentum Mill., cv. 'Better Bush') plant response to root restriction. 1. Root respiration and ethylene generation. J. Expt. Bot. 42:12411249.

Peterson, T.A. and D.T. Krizek. 1992. A flow-through hydroponic system for the study of root restriction. J. Plant Nutr. 15:893-911.

Richards, D. and R.N. Rowe. 1977. Effects of root restriction, root pruning and 6-benzylaminopurine on the growth of peach seedlings. Ann. Bot., 41:729-740.

Ruff, M.S., D.L. Krizek, R.M. Mirecki, and D.W. Inouye. 1987. Restricted root zone volume: Influence on growth and development of tomato. J. Amer. Soc. Hort. Sci. 112:763-769.

Warncke, D.D. and S.A. Barber. 1974. Root development and nutrient uptake by corn grown in solution culture. Agron. J. 66:514-516.

Wiersum, L.K. 1966. Calcium content of fruits and storage tissues in relation to the mode of water supply. Acta Bot. Ned. 15:406-418.

Wild, A., V. Skarlou, C.R. Clement, and R.W. Snaydon. 1974. Comparison of potassium uptake by four plant species grown in sand and in flowing solution culture. J. Appl. Ecol. 11:801-812.

Winsor, G. and P. Adams. 1987. Glasshouse crops, In: J.B.D. Robinson (ed.). Diagnosis of mineral disorders in plants. vol. 3. Her Majesty's Stationery Office, London. 